\title{
The Fourier transform infrared spectroscopy (FTIR) analysis for the clay mineralogy studies in a clastic reservoir
}

\author{
Golnaz Jozanikohan $^{1}$ (D) Mohsen Nosrati Abarghooei ${ }^{2}$
}

Received: 17 August 2021 / Accepted: 27 December 2021 / Published online: 9 January 2022

(c) The Author(s) 2022

\begin{abstract}
The complete characteristics knowledge of clay minerals is necessary in the evaluation studies of hydrocarbon reservoirs. Ten samples taken from two wells in a heterogeneous clastic gas reservoir formation in NE Iran were selected to conduct the transmission Fourier transform infrared spectroscopy (FTIR) tests for the clay mineralogy studies. The FTIR analysis showed that there were clear signs of clay minerals in all samples. The wavenumber region of the clay minerals in FTIR tests was detected to be $3621,3432,1034$, and $515 \mathrm{~cm}^{-1}$ for illite, $3567,3432,1613,1088,990,687,651$, and $515 \mathrm{~cm}^{-1}$ for magnesium-rich chlorite, $3700,3621,3432,1034,687$, and $463 \mathrm{~cm}^{-1}$ for kaolinite, and 3567, 1088, 990, and $463 \mathrm{~cm}^{-1}$ for glauconite. After screening of samples by the FTIR method, the samples were then analyzed by powder X-ray diffraction (PXRD), wavelength dispersive X-ray fluorescence (WDXRF), and scanning electron microscopy (SEM). The PXRD and SEM result showed illite was by far the most common clay present. Kaolinite, magnesium-rich chlorite, and traces of smectite and the mixed-layer clays of both the illite-smectite and chlorite-smectite types were also recognized. The combination of PXRD and WDXRF results could quantify the clay abundances in the each well too. It was concluded that the FTIR analysis successfully could show the absorption bonds of all constituent clays. However, the infrared absorption spectra of mixed-layer clays overlapped those of the respective constituents of each mixed-layer minerals. This can be considered as the evidence of the usefulness of FTIR technique in the screening of the samples for the clay mineralogy studies.
\end{abstract}

Keywords Transmission Fourier transform infrared spectroscopy (FTIR) · Powder X-ray diffraction (PXRD) · Wavelength dispersive X-ray fluorescence (WDXRF) · The clay minerals

\section{Introduction}

The clay minerals, even in the small amounts, strongly affect the properties of petroleum reservoirs as well as the response of most well logging tools (Attia et al. 2015; Abudeif et al. 2016a, 2016b, 2018; Hasan et al. 2020; Radwan 2020; Radwan et al. 2020; Jiu et al. 2021). Thus, a comprehensive knowledge of clay mineralogy is needed for both the reservoir modeling and the interpretation of wire-line log data (Hong et al. 2020; Wang et al. 2020; Radwan, 2021a;

Golnaz Jozanikohan

gjkohan@ut.ac.ir

Mohsen Nosrati Abarghooei

nosrati21503@gmail.com

1 School of Mining, College of Engineering, University of Tehran, 14399-57131 Tehran, Iran

2 Department of Mining and Metallurgical Engineering, Yazd University, 8915818411 Yazd, Iran
Radwan et al., 2021a). In addition, clays may react with drilling fluids causing formation damage (Radwan et al. 2019a; Radwan et al. 2019b; Radwan 2020, 2021b; Radwan et al. 2021 b, 2021c), so a good knowledge of clay mineralogy may influence the choice of drilling fluids and additives. Number of techniques has been used to characterize the individual clay minerals (Ashraf et al. 2019; Ali et al. 2020) of which the X-ray diffraction (XRD) is the most popular one (Jozanikohan et al. 2016; Abd Elmola et al. 2020). The conventional XRD method needs careful sample preparation besides several specialized treatments to identify particular clay minerals (Kumar \& Lingfa 2020). However, such treatments run the risk of destroying or altering clays of interest (Moore \& Reynolds 1989). Infrared spectroscopy (IR) is a widely used analytical technique in the geosciences studies (Stanienda 2016) and sometimes used as a screening tool to recognize the samples containing clays for more sophisticated and time-consuming procedures such as XRD. The FTIR analysis has several advantages over the XRD including: (i) the 
preparation of powder samples is quite easy and fast $(\mathrm{KBr}$ pellets normally take 5-8 min to be ready); (ii) the collection of spectrum is fast (it takes almost 1-2 min), (iii) only small amount of samples (about $0.3 \mathrm{~g}$ ) are required; (iv) additional treatments of samples are not required, and (v) it is cheap compared to the XRD method (Madejová \& Komadel 2001; Ji et al. 2009; Pálková et al. 2020). The spectral absorption characteristics in the IR spectra are qualitatively related to the variations in the constituent minerals and can be used for investigating the crystalline structure, type of bonding, and some chemical information on the clay minerals (Madejová, 2003; Du et al. 2010; Yan et al. 2021). The Fourier transforms of IR spectra are being increasingly used to aid the clay mineral identification (Madejová, 2003; Vaculíková \& Plevová, 2005; Nayak \& Singh 2007; Worasith et al. 2011; Repacholi 1994; Djomgoue \& Njopwouo 2013; Chen et al. 2020; El-Shater et al. 2021). The high signal-to-noise ratios as well as the high speed of data acquisition and accuracy enhancement in frequency measurements have made the FTIR method a suitable candidate for the initial analysis method to characterize the clay minerals (Madejová, 2003; Ma et al. 2021).

The clay minerals consist of hydroxyl groups, tetrahedral and octahedral sheets, and interlayer cations (Meunier 2005). The valuable "fingerprint" absorptions in clay mineral characterization are mainly contributed by the stretching and bending vibration bands of $\mathrm{Si}-\mathrm{O}, \mathrm{Al}-\mathrm{O}$, and $\mathrm{O}-\mathrm{H}$ (Farmer 2000). The absorption of IR radiation by individual clay minerals are determined by the strength, length, and force constants of chemical bonds in the structures of clay minerals as well as crystalline order, shape and size of particles, atomic mass, and some symmetry-related elements such as the unit cell constraints of the symmetry, and finally the local site symmetry of each individual atom within the unit cell (Repacholi 1994). Different aspects of clay mineralogy, including the study of relationships between the clay chemical composition and the absorption band variations, and the study of variations in the absorption features after acid treatment/heating were carried out using the FTIR analysis (Madejová et al. 1998; Tyagi et al. 2006). In nature, clay minerals are often accompanied by quartz, K-feldspar and plagioclase, carbonates, iron oxide, and/or sulfide or sulfates (Meunier 2005). Differences in the absorption bands of these non-clay minerals make them clearly distinguishable from each other. The clay minerals can exclusively be differentiated from the other minerals by the absorption bands of structural $\mathrm{OH}$ and $\mathrm{Si}-\mathrm{O}$ groups. However, each clay mineral may have similar types of bonds, which make them more difficult to distinguish (Farmer 2000).

The contribution of the FTIR method in the oil and gas industry has been included, but not limited to the determinations of oil acidity ( $\mathrm{Li} 2009$ ), the assessment of the shale gas and shale oil potentials (Wright et al. 2015), the study of the petroleum fluid inclusions (Li \& Parnell 2003), the assessment of the pyrolysis gases (Primpke et al. 2020), the identification of the insoluble fraction of pyrolysis oil (Scholze \& Meier 2001), the composition characterization of the collected bio-oils (Shen et al. 2010), the study of the chemical structures of individual macerals as well as their relative generation kinetics (Lin \& Ritz 1993).

Some previous FTIR studies on the pure clay minerals have been carried out (Madejová, 2003; Nayak \& Singh 2007; Repacholi 1994; Du et al. 2010), but analogously little consideration has been given to the identification of the clay minerals in the clastic formations with complex lithologies by the transmission FTIR method (Adamu 2010). Since the Shurijeh formation is considered as a heterogeneous sandstone reservoirs, it needs to be mineralogically identified in the eastern part of Kopet-Dagh sedimentary Basin, NE Iran. In this research, the ability of one of the most famous spectral analysis methods, i.e., transmission Fourier transform infrared (FTIR) spectroscopy, as a screening tool, has been investigated to select the samples containing clays, for further studies along with the traditional methods such as powder X-ray diffraction (PXRD), wavelength dispersive $\mathrm{X}$-ray fluorescence (WDXRF), and the scanning electron microscopy (SEM) analysis. The results of this study will aid the geoscientists in oil and gas upstream industries to evaluate and screen the samples for the purpose of clay mineralogy studies in reservoir evaluation stages more fast and convenient, before conducting expensive and time-consuming analysis such as the XRD, SEM, and XRF.

\section{Experimental methods}

\section{Materials}

The coring operation was conducted on the reservoir formation at depths of $3202.8-3210 \mathrm{~m}$ and $3180-3207.6 \mathrm{~m}$ of the gas-producing and non-producing wells, respectively. A total of 76 core samples was taken almost every one and a half meter from the Shurijeh formation in a gas-producing well and a non-producing one. The wells are located in the Iranian part of eastern Kopet-Dagh Basin, NE Iran (Fig. 1). The understudy reservoir formation is mainly composed of sandstone with interlayer of clay minerals. Therefore, all of the collected core samples did not contain the clay minerals in the major quantities. Ten samples were carefully selected based on the macroscopic features related to the lithological variations such as texture, grain size, cementation, beddings, and looseness degree to determine the samples containing the most amounts of clay minerals for further detailed analysis methods. Five samples, labeled with "GP," were taken from the gas-producing well between the depths of 


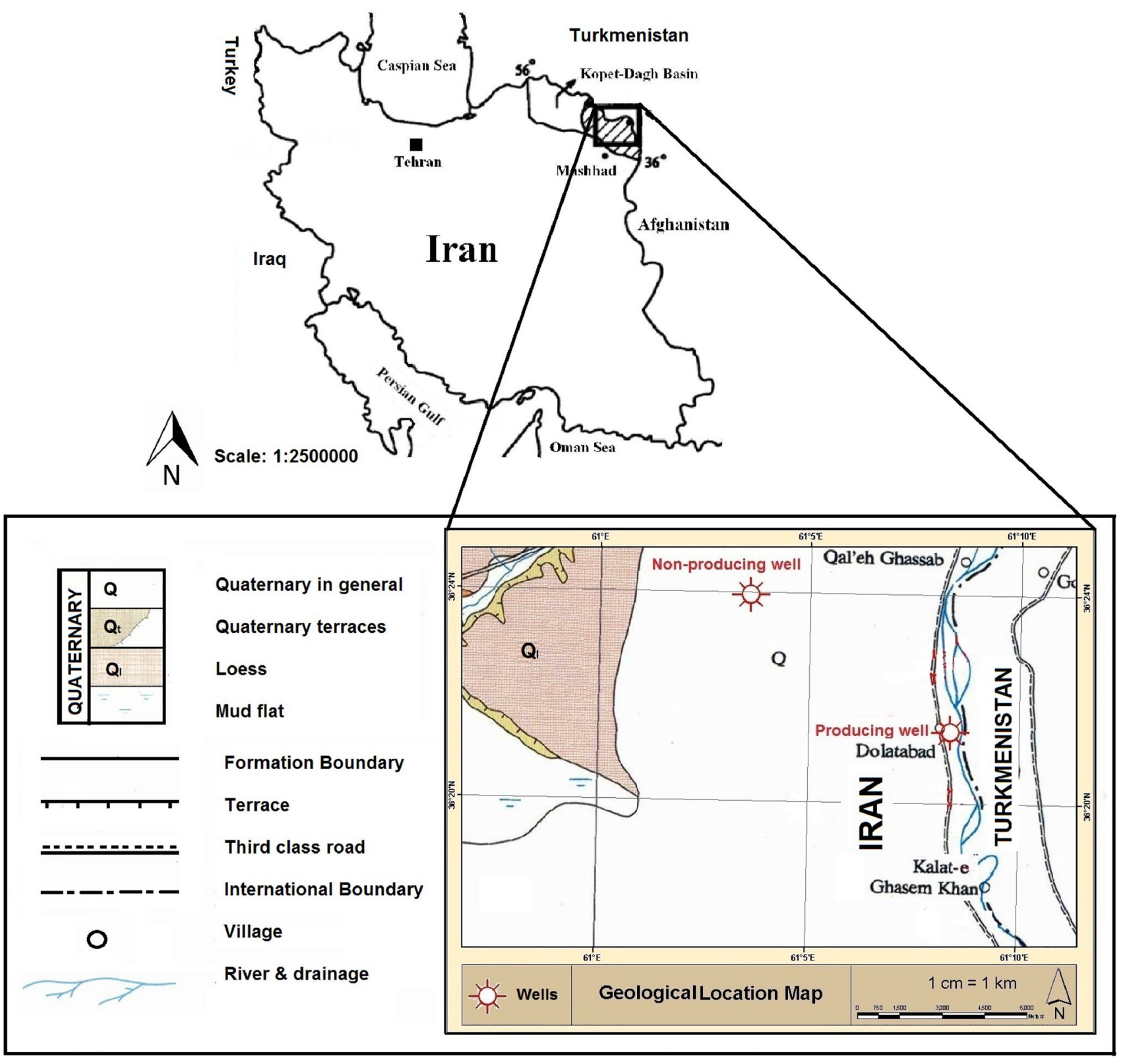

Fig. 1 Geographic location map of the studied area, modified from Jozanikohan et al. 2015

3204.6 and $3209.1 \mathrm{~m}$, and the remaining samples, labeled with "NP," were selected from depths of 3180-3205.57 m in the non-producing well. The outside parts of each core sample were carefully removed to avoid from the possible contaminations or oxidation effects. The samples were then ground to pass through a $200-\mu \mathrm{m}$ sieve and carefully mixed to give a homogeneous mixture. The location of each sample is shown in Fig. 2. All of the ten samples were made ready to be analyzed by the FTIR method.

\section{Methods}

Transmission Fourier transform infrared (FTIR) spectroscopy

The vibrational spectra for all samples were obtained using a Bruker TENSOR 27 FTIR spectrometer, equipped with an infrared source, potassium bromide beam splitter, and high sensitive DigiTectTMdetector system. Disks of 13-mm diameter and 1-2-mm thickness, consisting of 
Fig. 2 Schematic core sample locations of the both wells. Sample codes and the lithoGas-producing well, and Left: logical units are shown. Right: Non-producing well

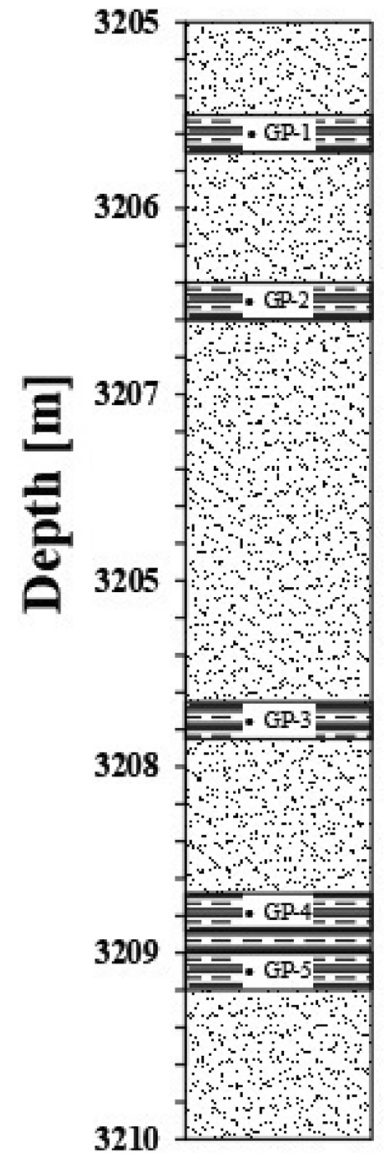

approximately $0.6 \mathrm{mg}$ sample gently dispersed in $200 \mathrm{mg}$ of $\mathrm{KBr}$, were carefully heated at $120{ }^{\circ} \mathrm{C}$ to minimize the amount of the absorbed water. Disks were then immediately and thoroughly scanned in the wavenumber region of $4000-400 \mathrm{~cm}^{-1}$ in transmission mode with a resolution of $4 \mathrm{~cm}^{-1}$ with 128 successive scans.

\section{Powder X-ray diffraction (PXRD) analysis}

The most important step in the quantitative XRD analysis is to prepare the samples with respect to all the possible sources of error. To gain a preliminary knowledge of the existing minerals, the randomly oriented powder samples were first exposed to the X-ray and analyzed. A Bruker AXS, D8 Advance X-ray powder diffractometer with $\mathrm{CuK}_{\alpha}$ radiation and a 2 theta/theta goniometer was used for the XRD analysis. Diffraction patterns of the samples were recorded by the step scanning from 4 to 70 degrees $(2 \theta)$, with a step size of $0.02^{\circ}$ and counting for $5 \mathrm{~s}$ per step at $40 \mathrm{kV}$ and $30 \mathrm{~mA}$.

Since the non-clays can cover up some basic reflections of the clay minerals, thus the non-clay separation is a necessary task which was performed based on the procedure described by Moore \& Reynolds (1989). The chemical

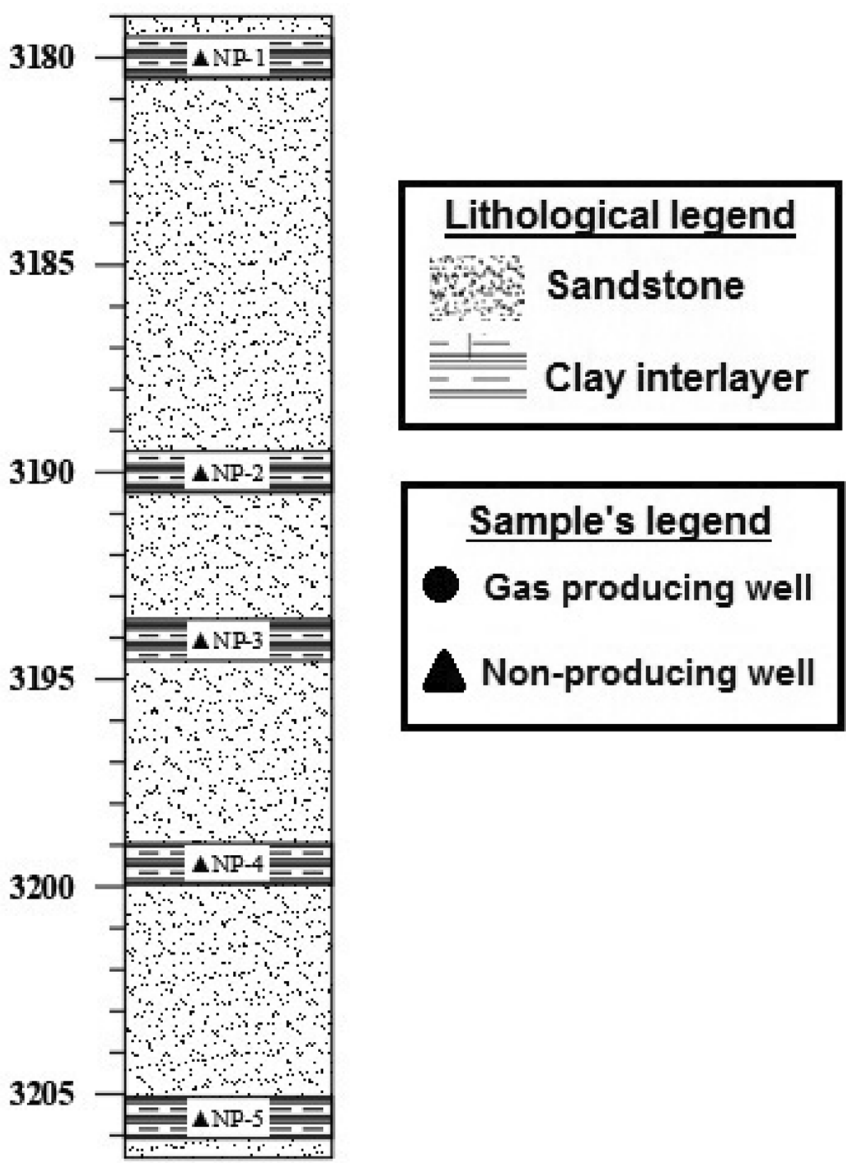

procedure for removal of XRD-proved non-clays, i.e., carbonate and sulfate minerals was to use the mild heating of the samples in a $\mathrm{C}_{2} \mathrm{H}_{3} \mathrm{NaO}_{2}-\mathrm{CH}_{3} \mathrm{COOH}$ buffer at $\mathrm{pH}=5$ (Jackson and Barak 2005), and also with using the sodium salt of $\mathrm{C}_{10} \mathrm{H}_{16} \mathrm{~N}_{2} \mathrm{O}_{8}$ (EDTA) (Bodine and Fernalld 1973), respectively. The iron oxide content of samples was negligible, and to avoid the risk of peak alteration in the mixed-layer clay minerals and or dissolution of iron-rich chlorite minerals, the iron content was not removed. The physical procedure for removal of other minerals such as quartz, plagioclase, and alkali feldspars was to settle them in a coarser residue of a wide-mouth glass tube, on the basis of Stokes' law. After several times of decantation the supernate, the clay fraction $(<2 \mu \mathrm{m})$ was extracted after $246 \mathrm{~min}$ at $20^{\circ} \mathrm{C}$. To prevent the clays from forming the polymineralic aggregates, a $0.1 \%$ solution of sodium hexametaphosphate was used in the each removal stage to disperse the clay minerals into the individual colloidal particles. Four small homogeneous glass slides were prepared from smearing the paste of $<2 \mu \mathrm{m}$. The XRD analyses were then performed from 4 to $40(2 \theta)$ degrees on four oriented clay small glass slides of naturally dried in the air, saturated with the $\mathrm{C}_{2} \mathrm{H}_{6} \mathrm{O}_{2}$ (ethylene glycol) vapor, boiled in the hydrochloric acid, and heated. 


\section{Wavelength dispersive X-ray fluorescence (WDXRF)}

Elemental analysis of the Shurijeh samples was performed on an automated Philips MagiX PRO wavelength dispersive X-ray fluorescence (WDXRF) spectrometer. Loss on ignition (LOI) was also determined (Table 1).

\section{The mineral quantification based on a combined analysis method (XRD-XRF)}

Several distinguished researches have proved that the mineral quantification could be done by means of combination of chemical and mineralogical data obtained from the XRF and XRD test, respectively (Paktunc 2001; Prandel et al. 2014; Jozanikohan et al. 2016; Zhang et al. 2020, 2021). Method basically includes solving a series of formulated simultaneous equations relating the chemical composition data to the percentages of each individual mineral (Eq. 1 to i).

$\alpha \_1 \mathrm{~A}+\mathrm{b} \_1 \beta+\cdots+\omega \_1 \mathrm{Z}=100 \mathrm{k} \_1$

$\alpha \_2 \mathrm{~A}+\mathrm{b} \_2 \beta+\cdots+\omega \_2 \mathrm{Z}=100 \mathrm{k} \_2$ $\alpha \_3 \mathrm{~A}+\mathrm{b} \_3 \beta+\cdots+\omega \_3 \mathrm{Z}=100 \mathrm{k} \_3$

$\vdots$

$\alpha \_\mathrm{i} A+\mathrm{b} \_\mathrm{i} \beta+\cdots+\omega \_\mathrm{i} Z=100 \mathrm{k} \_\mathrm{i}$

where $\alpha \_i, \beta \_i, \ldots, \omega \_i$, and $k \_i$, display the ith element percentages in the each individual mineral phases and the whole bulk rock, respectively. $\mathrm{A}, \mathrm{B}, \ldots$, and $\mathrm{Z}$ indicate the present phases percentages in the studied sample.

In the current study, the combined XRD-XRF method has been used for the phase quantification purpose. Having identified the main constituents of the samples and the relevant chemical formula from the PXRD analysis, a quantification method based on what explained above were applied, using the elemental analyses provided from the XRF data to estimate the mineral abundances.

The average percentages of each individual phase and each of the clay minerals are given in Tables 2 and 3, respectively.

Table 1 XRF results of the Shurijeh core samples

\begin{tabular}{lllllllllll}
\hline Code & $\mathrm{MgO}(\%)$ & $\mathrm{Al}_{2} \mathrm{O}_{3}(\%)$ & $\mathrm{SiO}_{2}(\%)$ & $\mathrm{SO}_{3}(\%)$ & $\mathrm{K}_{2} \mathrm{O}(\%)$ & $\mathrm{CaO}(\%)$ & $\mathrm{Fe}_{2} \mathrm{O}_{3}(\%)$ & $\mathrm{Na}_{2} \mathrm{O}(\%)$ & $\mathrm{LOI}(\%)$ & $\mathrm{Total}(\%)$ \\
\hline GP-1 & 1.20 & 11.28 & 74.21 & 0.65 & 2.50 & 3.76 & 0.72 & 3.26 & 2.42 & 100 \\
GP-2 & 0.59 & 8.20 & 68.59 & 7.70 & 2.00 & 8.19 & 1.23 & 1.47 & 2.03 & 100 \\
GP-3 & 1.99 & 12.24 & 64.84 & 4.29 & 3.53 & 5.47 & 3.14 & 1.38 & 3.12 & 100 \\
GP-4 & 4.43 & 9.51 & 65.26 & 0.00 & 2.92 & 5.71 & 2.99 & 0.82 & 8.36 & 100 \\
GP-5 & 1.68 & 5.92 & 69.20 & 6.00 & 2.04 & 8.04 & 0.71 & 1.20 & 5.21 \\
NP-1 & 3.41 & 10.24 & 66.14 & 1.18 & 2.33 & 5.93 & 1.35 & 2.66 & 6.76 & 100 \\
NP-2 & 1.60 & 13.41 & 66.16 & 1.71 & 3.27 & 5.70 & 3.08 & 1.59 & 3.48 & 100 \\
NP-3 & 2.61 & 11.34 & 57.59 & 6.29 & 3.04 & 9.09 & 2.17 & 1.24 & 6.63 & 100 \\
NP-4 & 3.90 & 13.06 & 53.22 & 4.35 & 3.00 & 9.79 & 2.61 & 1.60 & 8.47 & 100 \\
NP-5 & 3.61 & 12.80 & 50.83 & 7.00 & 2.92 & 10.05 & 4.42 & 1.09 & 7.28 & 100 \\
\hline
\end{tabular}

Table 2 Mineral content of the Shurijeh core samples

\begin{tabular}{|c|c|c|c|c|c|c|c|c|}
\hline Code & Quartz (\%) & Plagioclase (\%) & K-feldspar (\%) & Anhydrite (\%) & Carbonate $(\%)$ & Hematite (\%) & Clays (\%) & Total (\%) \\
\hline GP-1 & 65.5 & 17.1 & 4.6 & 1.1 & 4.0 & 0.0 & 7.7 & 100 \\
\hline GP-2 & 61.5 & 12.1 & 4.0 & 13.1 & 3.0 & 0.0 & 6.3 & 100 \\
\hline GP-3 & 53.0 & 12.5 & 6.1 & 7.3 & 3.7 & 0.8 & 16.6 & 100 \\
\hline GP-4 & 56.1 & 9.7 & 4.1 & 0.0 & 15.3 & 1.1 & 13.7 & 100 \\
\hline GP-5 & 64.4 & 6.6 & 3.0 & 10.2 & 8.3 & 0.0 & 7.5 & 100 \\
\hline NP-1 & 47.7 & 24.5 & 6.0 & 2.0 & 13.0 & 0.0 & 6.8 & 100 \\
\hline NP-2 & 54.7 & 15.7 & 4.9 & 2.9 & 5.5 & 1.1 & 15.2 & 100 \\
\hline NP-3 & 46.2 & 12.6 & 3.7 & 10.7 & 11.2 & 1.1 & 14.5 & 100 \\
\hline NP-4 & 39.9 & 18.2 & 3.2 & 7.4 & 15.4 & 1.5 & 14.4 & 100 \\
\hline NP-5 & 39.3 & 13.2 & 2.0 & 11.9 & 11.9 & 2.9 & 18.8 & 100 \\
\hline
\end{tabular}


Table 3 Clay contents of the Shurijeh core samples, obtained from the XRD test

\begin{tabular}{lllllllr}
\hline Code & Kaolinite (\%) & Chlorite (\%) & Illite (\%) & Glauconite (\%) & Smectite (\%) & $\begin{array}{l}\text { Mixed- } \\
\text { layer Clays } \\
(\%)\end{array}$ & Total (\%) \\
\hline GP-1 & 1.6 & 1.3 & 2.8 & 2.0 & 0.0 & 0.0 & 7.7 \\
GP-2 & 1.1 & 1.8 & 1.7 & 1.7 & 0.0 & 0.0 & 6.3 \\
GP-3 & 4.7 & 5.7 & 6.2 & 0.0 & 0.0 & 0.0 & 16.6 \\
GP-4 & 1.8 & 4.6 & 6.5 & 0.0 & 0.8 & 0.0 & 13.7 \\
GP-5 & 1.0 & 1.1 & 2.7 & 2.7 & 0.0 & 0.0 & 7.5 \\
NP-1 & 2.0 & 3.0 & 0.5 & 1.3 & 0.0 & 0.0 & 6.8 \\
NP-2 & 2.5 & 3.4 & 3.1 & 6.2 & 0.0 & 0.0 & 15.2 \\
NP-3 & 2.4 & 2.6 & 6.0 & 0.0 & 0.0 & 3.5 & 14.5 \\
NP-4 & 2.4 & 2.7 & 8.1 & 0.0 & 0.0 & 1.2 & 14.4 \\
NP-5 & 4.1 & 3.7 & 9.5 & 0.0 & 0.0 & 1.5 & 18.8 \\
\hline
\end{tabular}

\section{The scanning electron microscopy (SEM) analysis}

The scanning electron microscopy technique (SEM) was engaged to characterize the morphology, geometry, and distribution patterns of clay minerals in some of the selected samples. The selection procedure was accomplished based on the clay content of each sample determined by the XRD method. The selected samples (i.e., GP-3, GP-4, NP-2, and NP-3) were fully coated with thin layers of gold-palladium for $60 \mathrm{~s}$. The SEM analyses were then conducted using a JEOL model JSM-840.

\section{The results}

The data in Table 1 show the chemical composition of ten mentioned core samples in both wells, obtained from the XRF test.

According to the whole-rock powder diffractometry, the main constituents of the samples from both wells are quartz, and plagioclase with the secondary minerals such as clays, anhydrite, carbonates (dolomite and calcite), and K-feldspar (Fig. 3a). Hematite was observed in some few samples. These XRD results were found extremely useful in the designing of the subsequent non-clay mineral removal steps (Fig. 3b). The identified clay minerals were kaolinite, illite, glauconite, chlorite, smectite, and mixed layers of illite-smectite, and chlorite-smectite types.

The obtained SEM images are shown in Fig. 4. It is clear from Fig. 4 that the most common pore filling clay minerals included kaolinite with platy morphology and illite as microfibers. In all of the studied samples, kaolinite were mainly found as several stacking of successive layers (e.g., Fig. 4a), and fully filled the pores. The fine illite fibers (Fig. 4b) were widely spread in the open pore space, changing the macro-porosities to micro-porosities. The assemblages of mixed-layer clays such as illite-smectite
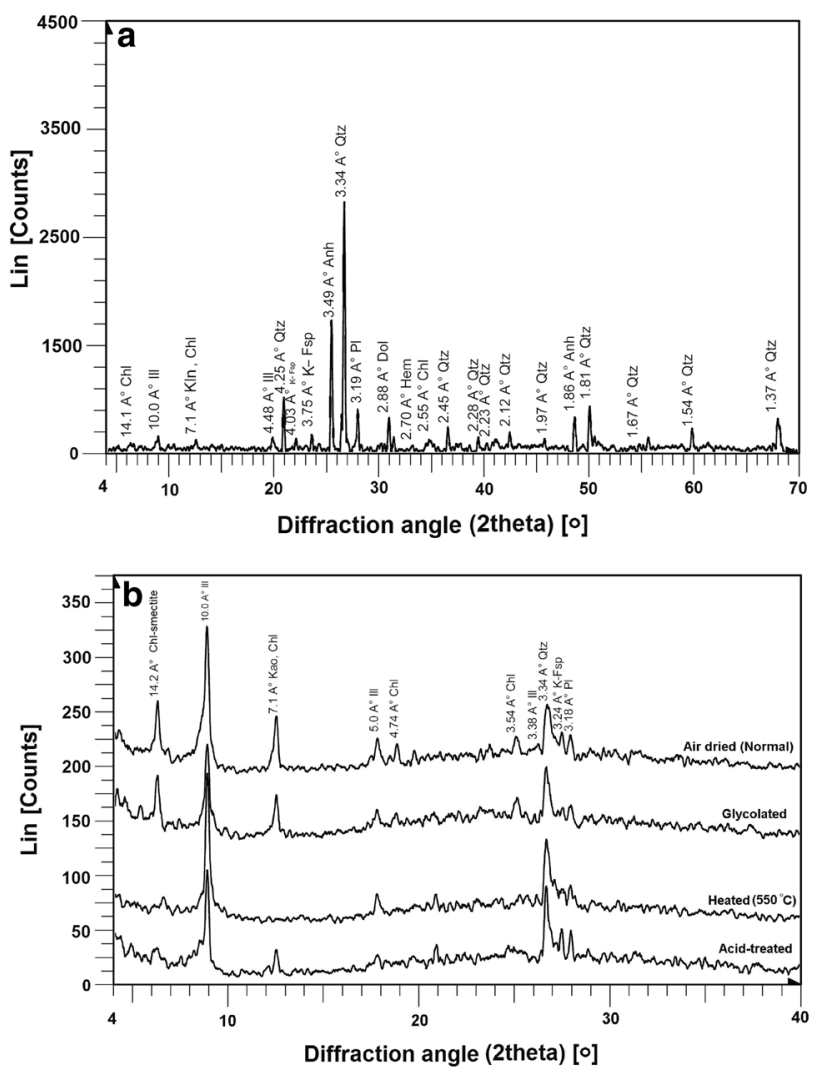

Fig. 3 a Whole-rock powder X-ray diffraction pattern of the samples under study (Sample code: NP-5); b The XRD diffraction pattern of the same sample. $\mathrm{Chl}=\mathrm{Chlorite}, \mathrm{Chl}-\mathrm{Smectite}=$ Chlorite smectite Ill = Illite, Kao= Kaolinite, Qtz= Quartz, Pl=Plagioclase, Hem $=$ Hematite, Anh = Anhydrite, Dol = Dolomite

are show in Fig. 4c. Figure 4d shows chlorite intercalated with kaolinite found as grain coatings. The restricted pore geometry characterized by the SEM test showed very fine confined polygons with maximum 1.5 micro-meter diameter. 
Fig. 4 SEM images of the samples understudy: a GP-3 at $7000 \mathrm{X}$ magnification, $15 \mathrm{kV}$, and $\mathrm{WD}=23 \mathrm{~mm}$; b GP-4 at 25500X magnification, $30 \mathrm{kV}$, and $\mathrm{WD}=23 \mathrm{~mm}$; $\mathbf{c N P}-2$ at $4000 \mathrm{X}$ magnification, $15 \mathrm{kV}$, and $\mathrm{WD}=24 \mathrm{~mm}$; and $\mathbf{d} \mathrm{NP}-3$ at $2500 \mathrm{X}$ magnification, $15 \mathrm{kV}$, and $\mathrm{WD}=24 \mathrm{~mm}$. Kao: kaolinite, Ill: Illite, Ill/Sm: Illitesmectite, Chl: chlorite
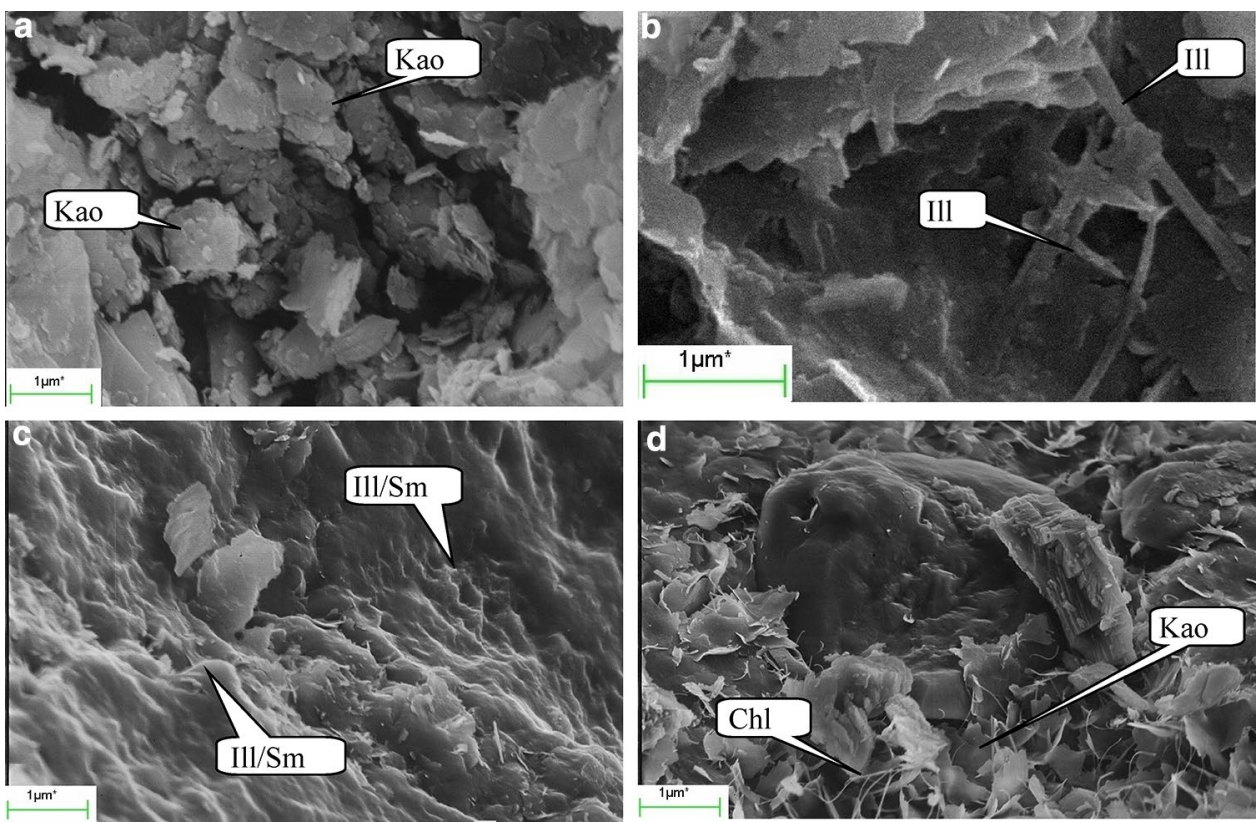

Figure 5 shows the infrared absorption spectra of the Shurijeh core samples. The splitting bands in the region of $800-400 \mathrm{~cm}^{-1}$ including $780,693,588,533,464$, and $428 \mathrm{~cm}^{-1}$ as well as one band at $1034 \mathrm{~cm}^{-1}$ indicate the feldspar presence (Farmer 2000). According to the reports of some researches ( $\mathrm{Ji}$ et al. 2009), the IR transmission spectra of carbonates include some distinctive features at $3050-2850 \mathrm{~cm}^{-1}, 2650-2500 \mathrm{~cm}^{-1}, 1790-1820 \mathrm{~cm}^{-1}$, $1400-1500 \mathrm{~cm}^{-1}, 877 \mathrm{~cm}^{-1}, 730 \mathrm{~cm}^{-1}$, and $710 \mathrm{~cm}^{-1}$. However, the peak at $877 \mathrm{~cm}^{-1}$ was only observed in the Shurijeh samples containing more than $10 \%$ carbonate (e.g., GP-4, NP-1, NP-3, NP-4, and NP-5). Dolomite, in comparison with calcite, shows three characteristic absorptions at 3020, 2626, and $730 \mathrm{~cm}^{-1}$ (Ji et al. 2009). Since these FTIR bands are all present in the samples whose codes were mentioned above, the dolomite was identified as one of the components of the samples. The sulfates are demonstrated to have strong absorption bands near $980 \mathrm{~cm}^{-1}, 450 \mathrm{~cm}^{-1}, 1150-1100 \mathrm{~cm}^{-1}$, and $675-590 \mathrm{~cm}^{-1}$ for $\mathrm{SO}_{4}$ different vibrations (Uusitalo et al. 2020). The vibrations observed at $650 \mathrm{~cm}^{-1}, 525 \mathrm{~cm}^{-1}$, $440-400 \mathrm{~cm}^{-1}$, and $300 \mathrm{~cm}^{-1}$ indicate the possible presence of hematite ( $\mathrm{Ji}$ et al. 2009). It is commonly believed that the $\mathrm{Si}-\mathrm{O}$ stretching vibrations are observed at $800-1200 \mathrm{~cm}^{-1}$, and its relative bending bands are found in the $400-600 \mathrm{~cm}^{-1}$ in the FTIR spectra of minerals (Matteson \& Herron 1993).

Although the samples were heated and dried before the analysis, the clear band in the area $1640-1600 \mathrm{~cm}^{-1}$ could be assigned to the deformation vibrations of $\mathrm{OH}$-adsorbed water (Kuligiewicz \& Derkowski 2017) or it can be related to the magnesium-rich chlorite. The strong bands between 3400 and $3750 \mathrm{~cm}^{-1}$ were assigned to the hydroxyl linkage $(\mathrm{O}-\mathrm{H})$ (Balan et al. 2001). However, the broad characteristic bands at 3450 and $3622 \mathrm{~cm}^{-1}$ suggest the possibility of hydration or layer hydrogen bonding in the samples (Kasprzhitskii et al. 2018). The well-resolved bands at $1120-1000 \mathrm{~cm}^{-1}$ region belong to the $\mathrm{Si}-\mathrm{O}$ stretching vibration of kaolinite (Madejová \& Komadel 2001). Kaolinite (1:1 layer) always shows a narrow, weak absorption at $3620 \mathrm{~cm}^{-1}$ due to the inner $\mathrm{OH}$ hydroxyls. Other hydroxyls give bands at higher $\mathrm{cm}^{-1}$, while illite (2:1 layer) and smectite show wide absorption in the region of $3650-2600 \mathrm{~cm}^{-1}$ with a shoulder peak (Balan et al. 2001). Most of the relatively strong $\mathrm{O}-\mathrm{H}$ vibration in smectite is from the water in the interlayer space of the silica tetrahedral sheet, which results in a wide absorption in the region of $3650-2600 \mathrm{~cm}^{-1}$ followed by the stronger absorption in about $1600 \mathrm{~cm}^{-1}$ (Changwen et al. 2007). The corresponding values for each vibration bands are given in Table 4.

The observed bands for each Shurijeh core sample in the range of $4000-400 \mathrm{~cm}^{-1}$ have been tentatively assigned (Fig. 5 and Table 5). The presences of bands at about $1086 \mathrm{~cm}^{-1}, 798 \mathrm{~cm}^{-1}, 778 \mathrm{~cm}^{-1}, 695 \mathrm{~cm}^{-1}$, and $468 \mathrm{~cm}^{-1}$ indicated that all of the samples were quartzrich. The absorption bands at 3696, 3622, 3450, 1033, $914,790,693,538$, and $468 \mathrm{~cm}^{-1}$ distinctly indicated that kaolinite was present in all of the samples. The observed absorption bands of kaolinite were in the agreement with findings of Yousefi et al. (2020). The clear signs of bands at 3696, 3622, 3450, 2369, 1633, 1033 and $790 \mathrm{~cm}^{-1}$ indicated that illite was also present in all of the core samples, and similar results were reported by previous researchers (Pineau et al. 2020). To differentiate kaolinite from illite, one should consider that the 1:1 layer clays (i.e., kaolinite) always show a narrow and weak absorption in 


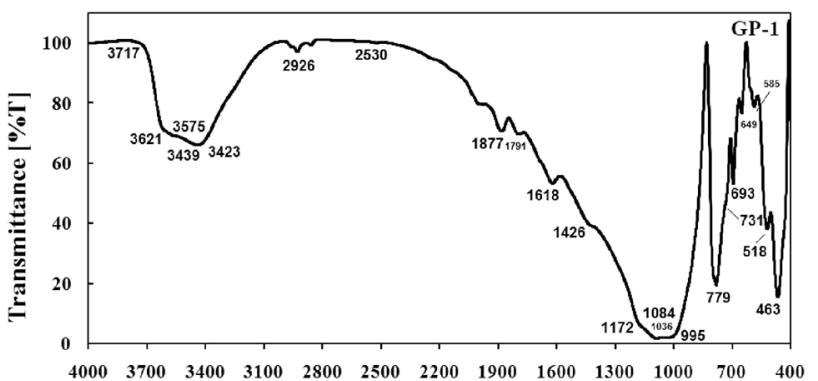

Wavenumber $\left[\mathrm{cm}^{-1}\right]$

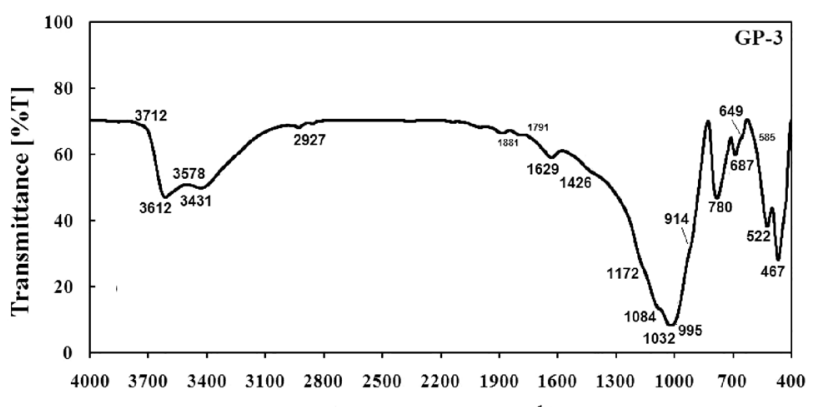

Wavenumber $\left[\mathbf{c m}^{-1}\right]$

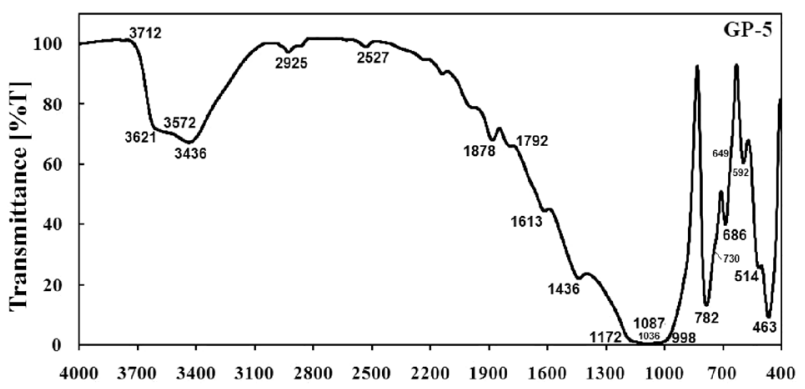

Wavenumber $\left[\mathrm{cm}^{-1}\right]$

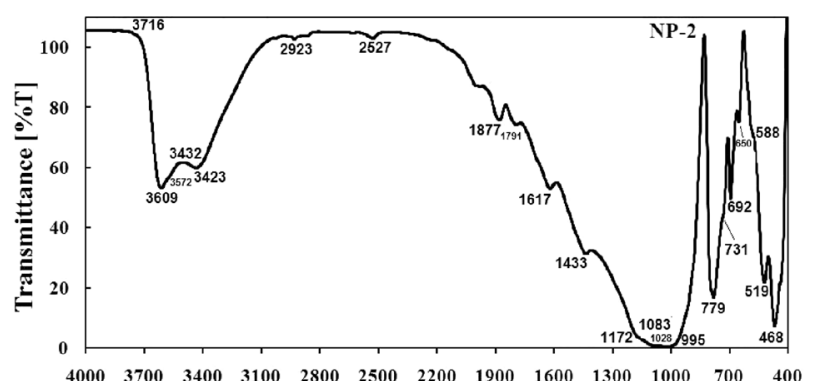

Wavenumber $\left[\mathrm{cm}^{-1}\right]$

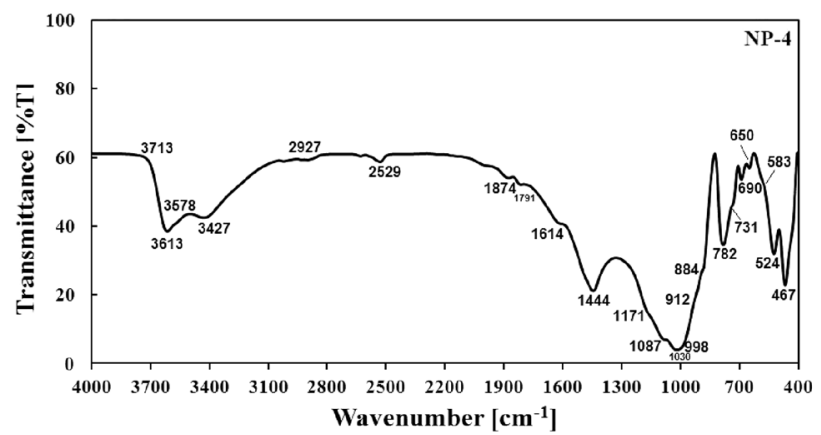

Fig. 5 FTIR spectra of core samples taken from the Shurijeh formation

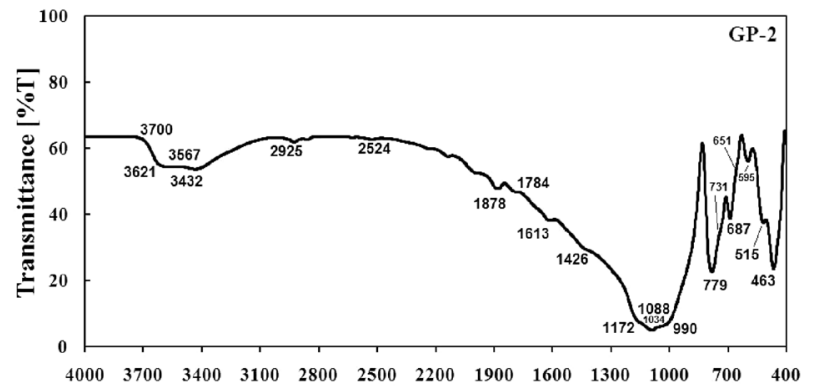

Wavenumber $\left[\mathrm{cm}^{-1}\right]$
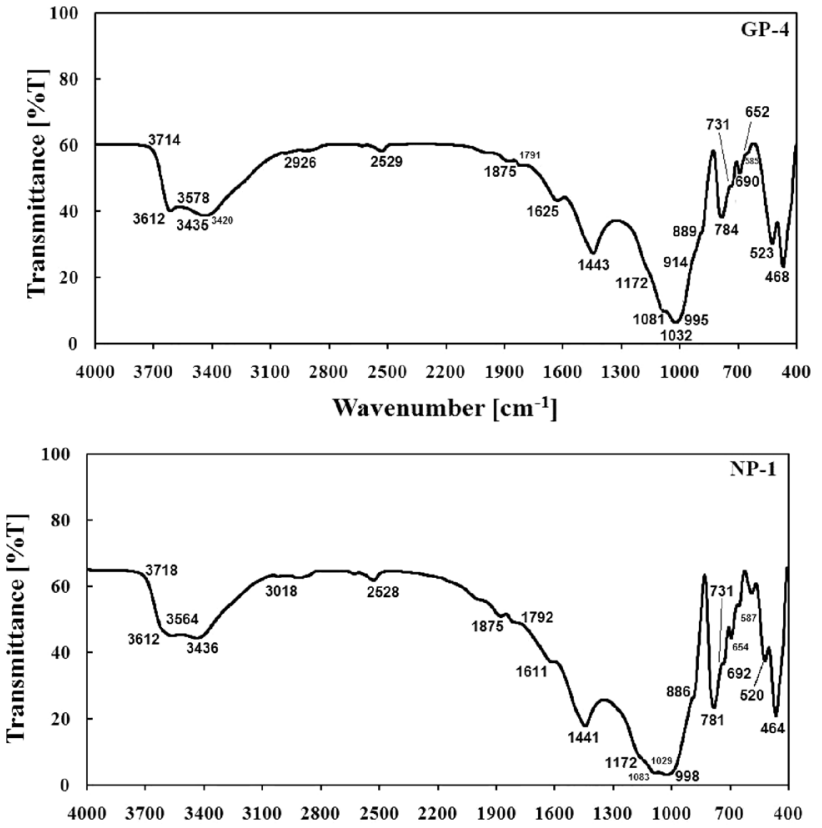

Wavenumber $\left[\mathrm{cm}^{-1}\right]$

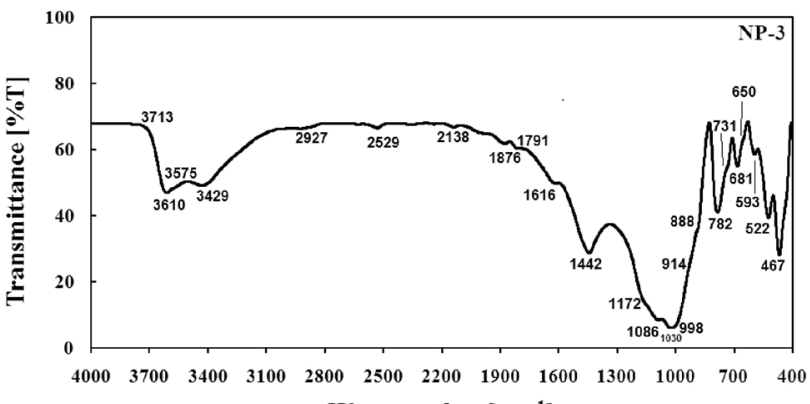

Wavenumber $\left[\mathbf{c m}^{-1}\right]$

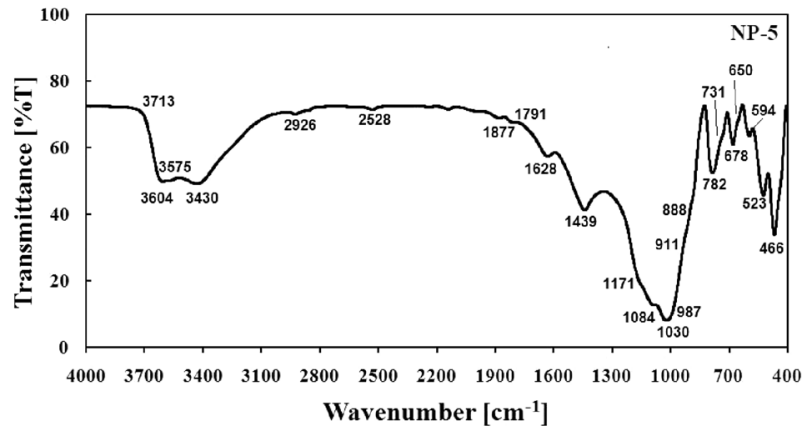


Table 4 Important mineral IR bands with their possible assignments (Farmer 2000; Balan et al. 2001; Nayak \& Singh 2007)

\begin{tabular}{|c|c|}
\hline Band $\left(\mathrm{cm}^{-1}\right)$ & Assignment \\
\hline 3703 & Surface hydroxyls \\
\hline 3695 & In-phase symmetric stretching vibration; internal surface $\mathrm{OH}$ groups \\
\hline 3669 & Out-of-plane $\mathrm{OH}$ stretching vibrations \\
\hline 3653 & Vibrations of two surface hydroxyls \\
\hline 3620 & Inner OH groups, lying between the sheets of tetrahedral and octahedral units \\
\hline 3430 & Adsorbed water vibrations $(\mathrm{H}-\mathrm{O}-\mathrm{H})$ \\
\hline 1633 & $\mathrm{H}-\mathrm{O}-\mathrm{H}$ stretching \\
\hline 1111 & Stretch vibration modes of $\mathrm{SO}_{4}$ tetrahedra \\
\hline 1102 & Stretch vibration modes of $\mathrm{SO}_{4}$ tetrahedra \\
\hline 1033 & $\mathrm{Si}-\mathrm{O}-\mathrm{Si}, \mathrm{Si}-\mathrm{O}$ stretching \\
\hline 1094 & Stretch vibration modes of $\mathrm{SO}_{4}$ tetrahedra \\
\hline 938 & Deformation bands of kaolinite \\
\hline 914 & $\mathrm{Al}_{2} \mathrm{OH}$ bending bands of kaolinite $\mathrm{AL}-\mathrm{O}-\mathrm{H}$ vibrations \\
\hline 844 & $\mathrm{AlMgOH}$ \\
\hline 790 & $\mathrm{Si}-\mathrm{O}$ stretching, $\mathrm{Si}-\mathrm{O}-\mathrm{Al}$ stretching, $(\mathrm{Al}, \mathrm{Mg})--\mathrm{O}-\mathrm{H}, \mathrm{Si}-\mathrm{O}-(\mathrm{Mg}, \mathrm{Al})$ stretching \\
\hline 693 & $\mathrm{Si}-\mathrm{O}$ stretching, $\mathrm{Si}-\mathrm{O}-\mathrm{Al}$ stretching \\
\hline 538 & $\mathrm{Si}-\mathrm{O}$ bending, $\mathrm{Si}-\mathrm{O}-\mathrm{Al}$ stretching \\
\hline 468 & $\mathrm{Si}-\mathrm{O}$ bending, $\mathrm{Si}-\mathrm{O}-\mathrm{Fe}$ stretching \\
\hline
\end{tabular}

$3600 \mathrm{~cm}^{-1}$, while $2: 1$ layer clays (i.e., illite) display wide absorption in the $2600 \sim 3650 \mathrm{~cm}^{-1}$ accompanied by a shoulder peak. The band at $914 \mathrm{~cm}^{-1}$ was only observed in samples containing more than $6 \%$ illite (e.g., GP-3, GP-4, NP-3, NP-4, and NP-5). The absorption bands at $3560 \mathrm{~cm}^{-1}, 3542-3534 \mathrm{~cm}^{-1}, 1076 \mathrm{~cm}^{-1}, 995 \mathrm{~cm}^{-1}$, and $463 \mathrm{~cm}^{-1}$ were interpreted as being due to the presence of glauconite. Peaks near $3574 \mathrm{~cm}^{-1}, 3420 \mathrm{~cm}^{-1}, 1630 \mathrm{~cm}^{-1}$, $1090 \mathrm{~cm}^{-1}, 995 \mathrm{~cm}^{-1}, 740-700 \mathrm{~cm}^{-1}, 661-650 \mathrm{~cm}^{-1}$, and $522 \mathrm{~cm}^{-1}$ were assigned to magnesium-rich chlorite. Characteristic features at $3621 \mathrm{~cm}^{-1}, 3420 \mathrm{~cm}^{-1}$, $1039 \mathrm{~cm}^{-1}, 914 \mathrm{~cm}^{-1}$, and $468 \mathrm{~cm}^{-1}$ were considered for the smectite presence. Whereas $1111 \mathrm{~cm}^{-1}, 1102 \mathrm{~cm}^{-1}$, $1094 \mathrm{~cm}^{-1}, 1015 \mathrm{~cm}^{-1}, 610 \mathrm{~cm}^{-1}, 659 \mathrm{~cm}^{-1}$, and $591 \mathrm{~cm}^{-1}$ were indicative of anhydrite, $3020 \mathrm{~cm}^{-1}, 2922 \mathrm{~cm}^{-1}$, $2874 \mathrm{~cm}^{-1}, 2626 \mathrm{~cm}^{-1}, 1798 \mathrm{~cm}^{-1}, 1426 \mathrm{~cm}^{-1}, 876 \mathrm{~cm}^{-1}$, and $730 \mathrm{~cm}^{-1}$ showed the possibility of the carbonate presence. Core samples containing mixed-layer clay minerals showed overlapped absorptions of both clay types which were interlayered together. For instance, the overlap of illite absorption band at $3630 \mathrm{~cm}^{-1}$ with smectite at 3635 and $3406 \mathrm{~cm}^{-1}$ (due to the occurrence of absorption of interlayer water) were observed in the samples containing mixed-layer illite-smectite.

Peak assignments were mostly consistent with those in the previous literature (Repacholi 1994; Madejová \& Komadel 2001; Madejová, 2003; Vaculíková \& Plevová, 2005; Changwen et al. 2007; Nayak \& Singh 2007; Ji et al. 2009; Liu et al. 2009; Papakosta et al. 2020; Pineau et al. 2020; Yousefi et al. 2020).

\section{Discussion}

From Fig. 5, it was obvious that the clay minerals were present in all samples; thus, it was decided to check the accuracy of FTIR prediction with XRD, and XRF methods to demonstrate the clay minerals existence in the samples.

It is clear from the results of the WDXRF test (Table 1) that the silicon was present in the major quantities in both wells, while the aluminum oxide was moderate and the other elements such as sulfur, calcium, potassium, sodium, magnesium, and iron were present in only minor amounts. Considering the mineralogy of the Shurijeh, the obtained results are meaningful.

The combined bulk powder X-ray diffractometry, X-ray fluorescence, and scanning electron microscopy (SEM) analyses of core samples showed that the main mineral constituents were quartz and plagioclase, with some quantities of other minerals such as the clay minerals, anhydrite, carbonates (calcite/dolomite), alkali feldspars, and hematite. The most important advantage of quantification using the XRF data is to allow for the quantitative calculations without the presence of any standard sample. The vast majority of clay minerals in the studied wells were illite, chlorite, and kaolinite. The most abundant clay mineral was illite in the both wells, but in few samples, there were signs of glauconite, smectite and mixed-layer clay minerals including I/S (illite-smectite) and chlorite-smectite. Among these rarely occurred clay minerals, glauconite was more common, while the smectite and 
Table 5 Shurijeh formation FTIR bands with mineral assignments

Code Mineral assignments (Band)

GP-1 Quartz $\left(1877,1172,1084,779,693,518\right.$, and $\left.463 \mathrm{~cm}^{-1}\right)$, feldspar (1036, splitting bands in the region $800-400 \mathrm{~cm}^{-1}$ including 779,693 , 585 , and $\left.463 \mathrm{~cm}^{-1}\right)$, traces of carbonates $\left(2926,2530,1791,1426\right.$, and $\left.731 \mathrm{~cm}^{-1}\right)$, traces of anhydrite $\left(995\right.$ and $\left.585 \mathrm{~cm}^{-1}\right)$, illite $(3621$, 3439,1036 , and $\left.518 \mathrm{~cm}^{-1}\right)$, magnesium-rich chlorite $\left(3575,3423,1618,1084,995,693,649\right.$, and $\left.518 \mathrm{~cm}^{-1}\right)$, kaolinite $(3717,3621$, $3439,1036,693$, and $\left.463 \mathrm{~cm}^{-1}\right)$, and glauconite $\left(3575,1084,995\right.$, and $\left.463 \mathrm{~cm}^{-1}\right)$

GP-2 Quartz $\left(1878,1172,1088,779,687,515\right.$, and $\left.463 \mathrm{~cm}^{-1}\right)$, feldspar $\left(1034\right.$, splitting bands in the region $800-400 \mathrm{~cm}^{-1}$ including 779 , 687, 595 , and $\left.463 \mathrm{~cm}^{-1}\right)$, anhydrite $\left(990\right.$ and $\left.595 \mathrm{~cm}^{-1}\right)$, traces of carbonates $\left(2926,2524,1784,1426\right.$, and $\left.731 \mathrm{~cm}^{-1}\right)$, illite $(3621,3432$, 1034 , and $\left.515 \mathrm{~cm}^{-1}\right)$, magnesium-rich chlorite $\left(3567,3432,1613,1088,990,687,651\right.$, and $\left.515 \mathrm{~cm}^{-1}\right)$, kaolinite $(3700,3621,3432$, 1034,687 , and $\left.463 \mathrm{~cm}^{-1}\right)$, and glauconite $\left(3567,1088,990\right.$, and $\left.463 \mathrm{~cm}^{-1}\right)$

GP-3 Quartz $\left(1881,1172,1084,780,687,522\right.$, and $\left.467 \mathrm{~cm}^{-1}\right)$, feldspar (1032, splitting bands in the region $800-400 \mathrm{~cm}^{-1}$ including 780,687 , 585 , and $\left.467 \mathrm{~cm}^{-1}\right)$, traces of carbonates $\left(2927,1791\right.$, and $\left.1426 \mathrm{~cm}^{-1}\right)$, traces of anhydrite $\left(995\right.$ and $\left.585 \mathrm{~cm}^{-1}\right)$, traces of hematite $(649$ and $\left.522 \mathrm{~cm}^{-1}\right)$, illite $\left(3612,3431,1032,914\right.$, and $\left.522 \mathrm{~cm}^{-1}\right)$, magnesium-rich chlorite $(3578,3431,1629,1084,995,687,649$, and $\left.522 \mathrm{~cm}^{-1}\right)$, and kaolinite $\left(3712,3612,3431,1032,687\right.$, and $\left.467 \mathrm{~cm}^{-1}\right)$

GP-4 Quartz (1875, 1172, 1081, 784, 690, 523, and $\left.468 \mathrm{~cm}^{-1}\right)$, feldspar (1032, splitting bands in the region $800-400 \mathrm{~cm}^{-1}$ including 784 , 690,585 , and $\left.468 \mathrm{~cm}^{-1}\right)$, carbonates $\left(2926,2529,1791,1443,889\right.$, and $\left.731 \mathrm{~cm}^{-1}\right)$, traces of hematite $\left(652\right.$ and $\left.523 \mathrm{~cm}^{-1}\right)$, illite $(3612$, $3435,1032,914$, and $\left.523 \mathrm{~cm}^{-1}\right)$, magnesium-rich chlorite $\left(3578,3435,1625,1081,995,690,652\right.$, and $\left.523 \mathrm{~cm}^{-1}\right)$, kaolinite $(3714$, $3612,3435,1032,690$, and $\left.468 \mathrm{~cm}^{-1}\right)$, and smectite $\left(3612,3420,1032,914\right.$, and $\left.468 \mathrm{~cm}^{-1}\right)$

GP-5 Quartz (1878, 1172, 1087, 782, 686, 514, and $\left.463 \mathrm{~cm}^{-1}\right)$, feldspar (1036, splitting bands in the region $800-400 \mathrm{~cm}^{-1}$ including 782,686 , 592 , and $\left.463 \mathrm{~cm}^{-1}\right)$, anhydrite $\left(998\right.$ and $\left.592 \mathrm{~cm}^{-1}\right)$, traces of carbonates $\left(2925,2527,1792,1436\right.$, and $\left.730 \mathrm{~cm}^{-1}\right)$, illite $(3621,3436$, 1036 , and $\left.514 \mathrm{~cm}^{-1}\right)$, magnesium-rich chlorite $\left(3572,3436,1613,1087,998,686,649\right.$, and $\left.514 \mathrm{~cm}^{-1}\right)$, kaolinite $(3712,3621,3436$, 1036, 686, and $\left.463 \mathrm{~cm}^{-1}\right)$, and glauconite $\left(3572,1087,998\right.$, and $\left.463 \mathrm{~cm}^{-1}\right)$

NP-1 Quartz $\left(1875,1172,1083,781,692,520\right.$, and $\left.464 \mathrm{~cm}^{-1}\right)$, feldspar $\left(1029\right.$, splitting bands in the region $800-400 \mathrm{~cm}^{-1}$ including 781,692 , 587 , and $\left.464 \mathrm{~cm}^{-1}\right)$, carbonates $\left(3018,2528,1792,1441,886\right.$, and $\left.731 \mathrm{~cm}^{-1}\right)$, traces of anhydrite $\left(998\right.$ and $\left.587 \mathrm{~cm}^{-1}\right)$, illite $(3612$, 3436,1029 , and $\left.520 \mathrm{~cm}^{-1}\right)$, magnesium-rich chlorite $\left(3564,3436,1611,1083,998,692,654\right.$, and $\left.520 \mathrm{~cm}^{-1}\right)$, kaolinite $(3718,3436$, 1029,692 , and $\left.464 \mathrm{~cm}^{-1}\right)$, and glauconite $\left(3564,1083,998,464 \mathrm{~cm}^{-1}\right)$

NP-2 Quartz $\left(1877,1172,1083,779,692,519\right.$, and $\left.468 \mathrm{~cm}^{-1}\right)$, feldspar $\left(1028\right.$, splitting bands in the region $800-400 \mathrm{~cm}^{-1}$ including 779,692 , 588 , and $\left.468 \mathrm{~cm}^{-1}\right)$, traces of carbonates $\left(2923,2527,1791,1433\right.$, and $\left.731 \mathrm{~cm}^{-1}\right)$, traces of anhydrite $\left(995\right.$ and $\left.588 \mathrm{~cm}^{-1}\right)$, traces of hematite $\left(650\right.$ and $\left.519 \mathrm{~cm}^{-1}\right)$, illite $\left(3609,3432,1028\right.$, and $\left.519 \mathrm{~cm}^{-1}\right)$, magnesium-rich chlorite $(3572,3423,1617,1083,995,692$, 650 , and $\left.519 \mathrm{~cm}^{-1}\right)$, and kaolinite $\left(3716,3609,3432,1028,692\right.$, and $\left.468 \mathrm{~cm}^{-1}\right)$, and glauconite $\left(3572,1083,995\right.$, and $\left.468 \mathrm{~cm}^{-1}\right)$

NP-3 Quartz $\left(1876,1172,1086,782,681,522\right.$, and $\left.467 \mathrm{~cm}^{-1}\right)$, feldspar $\left(1030\right.$, splitting bands in the region $800-400 \mathrm{~cm}^{-1}$ including 782,681 , 593 , and $\left.467 \mathrm{~cm}^{-1}\right)$, carbonates $\left(2927,2529,1791,1442,888\right.$, and $\left.731 \mathrm{~cm}^{-1}\right)$, anhydrite $\left(998\right.$ and $\left.593 \mathrm{~cm}^{-1}\right)$, traces of hematite $(650$ and $\left.522 \mathrm{~cm}^{-1}\right)$, illite $\left(3610,3429,1030,914\right.$, and $\left.522 \mathrm{~cm}^{-1}\right)$, magnesium-rich chlorite $(3575,3429,1616,1086,998,681,650$, and $\left.522 \mathrm{~cm}^{-1}\right)$, and kaolinite $\left(3713,3610,3429,1030,681\right.$, and $\left.467 \mathrm{~cm}^{-1}\right)$

NP-4 Quartz (1874, 1171, 1087, 782, 690, 524, and $\left.467 \mathrm{~cm}^{-1}\right)$, feldspar (1030, splitting bands in the region $800-400 \mathrm{~cm}^{-1}$ including 782 , 690,583 , and $\left.467 \mathrm{~cm}^{-1}\right)$, carbonates $\left(2927,2529,1791,1444,884\right.$, and $\left.731 \mathrm{~cm}^{-1}\right)$, traces of anhydrite $\left(998\right.$ and $\left.583 \mathrm{~cm}^{-1}\right)$, traces of hematite $\left(650\right.$ and $\left.524 \mathrm{~cm}^{-1}\right)$, illite $\left(3613,3427,1030,912\right.$, and $\left.524 \mathrm{~cm}^{-1}\right)$, magnesium-rich chlorite $(3578,3427,1614,1087,998$, 690,650 , and $\left.524 \mathrm{~cm}^{-1}\right)$, and kaolinite $\left(3713,3613,3427,1030,690\right.$, and $\left.467 \mathrm{~cm}^{-1}\right)$

NP-5 Quartz $\left(1877,1171,1084,782,678,523\right.$, and $\left.466 \mathrm{~cm}^{-1}\right)$, feldspar $\left(1030\right.$, splitting bands in the region $800-400 \mathrm{~cm}^{-1}$ including 782,678 , 594 , and $\left.466 \mathrm{~cm}^{-1}\right)$, carbonates $\left(2926,2528,1791,1439,888\right.$, and $\left.731 \mathrm{~cm}^{-1}\right)$, anhydrite $\left(987\right.$ and $\left.594 \mathrm{~cm}^{-1}\right)$, traces of hematite $(650$ and $\left.523 \mathrm{~cm}^{-1}\right)$, illite $\left(3604,3430,1030,911\right.$, and $\left.523 \mathrm{~cm}^{-1}\right)$, magnesium-rich chlorite $(3575,3430,1628,1084,987,678,650$, and $\left.523 \mathrm{~cm}^{-1}\right)$, and kaolinite $\left(3713,3604,3430,1030,678\right.$, and $\left.466 \mathrm{~cm}^{-1}\right)$

mixed-layer clays were only found in one or two samples of the non-producing well. The detailed quantitative XRD analysis yielded average clay mineral amounts which varied from 6.3 weight percent in the gas-producing well to the 18.8 weight percent in the non-producing well.

The wide variation in the percentage of clay minerals in the Shurijeh formation was due to the different depth of core samples. As a matter of fact, diagenetic changes occurred with an increase in the depth of burial which resulted in the generation of clay minerals. Apparently, the alteration of K-feldspar and plagioclase resulted in high amounts of illite. The existence of mixed-layer clay minerals proved that the smectite into illite transformation, a global phenomenon
(Blanc et al. 2021; Hucheng et al. 2021) was occurred in the Shurijeh formation with increasing depth too. Considering the impacts of clay mineralogy in a clastic reservoir (Ashraf et al. 2020, 2021), the illite, chlorite, and kaolinite could greatly affect on the reservoir parameters such as porosity and permeability.

The exact amount of each clay mineral in the both wells was determined by PXRD results which were combined by WDXRF data, and the XRD results played an important role on the evaluation of reservoir quality of the Shurijeh formation. Having known the volume of clay minerals, the reservoir parameters such as water saturation, porosity and permeability were estimated with more 
accuracy (Jozanikohan 2017). It is known that an over/ under-estimation of this parameter $\left(\mathrm{V}_{\mathrm{cl}}\right)$ minerals can result in a wrong estimation of water saturations that are too low/high, therefore making the reservoir look productive or resulting in the bypassing of a productive zone. It can also effect on the calculation of effective porosities which are used to determine both the effective water saturations and the net pay (Causey 1991).

As a matter of fact, the FTIR pattern of a natural sample which includes a mixture of minerals is hard to interpret than for tests conducted on monomineralogical samples. Individual minerals in complex samples can be easily distinguished from each other, if enough attention is given. The $\mathrm{O}-\mathrm{H}$ and $\mathrm{Si}-\mathrm{O}$ groups of clay minerals make different absorption bands in the FTIR spectra over the range $4000-400 \mathrm{~cm}^{-1}$, making it easy to differentiate each group of clay minerals. It is known that the most important region of the spectrum for the identification of aluminous minerals is the stretching vibrations of $\mathrm{OH}$ groups at $3800-3300 \mathrm{~cm}^{-1}$ (Pineau et al. 2020). However, this can be often hindered by absorbed water. The other main absorption region in transmittance spectra of clay minerals is $1200-400 \mathrm{~cm}^{-1}$ ( $\mathrm{Si}-\mathrm{O}$ stretching and bending absorptions, and $\mathrm{OH}$ bending region). The stretching modes of Al-O are found in the $1200-700 \mathrm{~cm}^{-1}$ range, while the bending modes dominate the $1500-600 \mathrm{~cm}^{-1}$ range (Madejová 2003). Any metal-O-H bending modes appear in the $600-950 \mathrm{~cm}^{-1}$ region (Farmer 2000). The absorption near $3620 \mathrm{~cm}^{-1}$ is typical for aluminum-rich clay minerals. The absorption bands for dioctahedral clay mineral are located in the $950-800 \mathrm{~cm}^{-1}$, while the absorption are shifted to lower regions in the range of $700-600 \mathrm{~cm}^{-1}$ in trioctahedral clay minerals (Madejová 2003). A slight change in the peak position of each sample was observed due to the substitutions in crystalline structure of minerals.

The recognition of hematite in some samples is significant, because hematite can cement the clay minerals together and make it difficult to be recognized with other analytical methods.

The result of infrared analysis evidently supported the mineral identification by PXRD method, and thus could be reliably used in fast clarifying the nature of the mineral constituents in formations with complex lithology. However, overlaps of some absorption, i.e., the splitting bands in $\mathrm{OH}$ region $4000-3000 \mathrm{~cm}^{-1}$, due to the presence of different mineral species, might make it difficult to distinguish different minerals from each other at the first sight.

Since the first stage in the shale gas and shale oil exploration or in the mineralogical characterization of reservoirs needs to screen a lot of samples in an optimal manner in terms of time and cost, the application of FTIR method as an easy and fast data providing method with less costs can be considered.

\section{Conclusions}

In particular, transmission Fourier transform infrared spectroscopy (FTIR) showed merits as an inexpensive, easy, and fast method in differentiating several types of clay minerals in the formations with complex lithology such as Shurijeh formation. The FTIR is also able to provide fundamental information on the clay minerals. All in one, the ease of use and the speed of the method have made the FTIR a suitable initial analysis for the purpose of clay minerals studies in reservoir characterization stages. The results obtained from this research can be a benefit to the geoscientists in upstream petroleum industry to screen the samples very fast before conducting more sophisticated and time-consuming analysis methods with the purpose of chemical and mineralogical characterizations, because the FTIR is able to do the both tasks, with more convenience and less costs. This method can be applied on the clastic reservoirs or on the shale oil and shale gas targets to be quickly assessed in terms of their potential. A series of Shurijeh core samples have been used to illustrate the usefulness of the technique in this study.

Acknowledgements Acknowledgements are due to the X-Ray laboratory, School of Mining, College of Engineering, University of Tehran, for kind participation and collaborations made throughout the present study.

Authors' contributions The first author has contributed to conducting the research as well as the interpretation of the results. The second author has taken the lead in writing the manuscript.

Funding This research received no specific grant from any funding agency in the public, commercial, or not-for-profit sectors.

Data availability The research data associated with this paper is available; it can be accessed, if anyone just emails the corresponding author.

\section{Declarations}

Conflict of interest Two authors of the paper declare that they have no conflict of interest.

Consent for publication The both authors give our consent for the publication of identifiable details, which can include figures, tables, case history, and details within the text ("Material") to be published in the Journal of Petroleum Exploration and Production Technology.

Ethics approval This material is the authors' own original work, which has not been previously published elsewhere. The paper is not currently being considered for publication elsewhere. The paper reflects the authors' own research and analysis in a truthful and complete manner. All procedures performed in studies involving performing the tests were in accordance with the ethical standards of the world. 
Open Access This article is licensed under a Creative Commons Attribution 4.0 International License, which permits use, sharing, adaptation, distribution and reproduction in any medium or format, as long as you give appropriate credit to the original author(s) and the source, provide a link to the Creative Commons licence, and indicate if changes were made. The images or other third party material in this article are included in the article's Creative Commons licence, unless indicated otherwise in a credit line to the material. If material is not included in the article's Creative Commons licence and your intended use is not permitted by statutory regulation or exceeds the permitted use, you will need to obtain permission directly from the copyright holder. To view a copy of this licence, visit http://creativecommons.org/licenses/by/4.0/.

\section{References}

Abd Elmola A, Asaad A, Patrier P, Beaufort D, Ballini M, Descostes M (2020) Clay mineral signatures of fault-related fluid flows in a sandstone reservoir: A case study from the Teloua Formation, Tim Mersoï Basin Niger. J African Earth Sci 168:103840

Abudeif AM, Attia MM, Radwan AE (2016a) Petrophysical and petrographic evaluation of Sidri member of Belayim Formation, Badri field, Gulf of Suez Egypt. J African Earth Sci 115:108-120

Abudeif AM, Attia MM, Radwan AE (2016b) New simulation technique to estimate the hydrocarbon type for the two untested members of Belayim Formation in the absence of pressure data, Badri Field, Gulf of Suez Egypt. Arabian J Geosci 9(3):218

Abudeif AM, Attia MM, Al-Khashab HM, Radwan AE (2018) Hydrocarbon type detection using the synthetic logs: a case study, Baba member, Gulf of Suez Egypt. J African Earth Sci 144:176-182

Adamu MB (2010) Fourier transform infrared spectroscopic determination of shale minerals in reservoir rocks. Nigerian J Basic Appl Sci 18(1):6-18

Ali M, Ma H, Pan H, Ashraf U, Jiang R (2020) Building a rock physics model for the formation evaluation of the lower Goru sand reservoir of the Southern Indus Basin in Pakistan. J Petrol Sci Eng 194:107461

Ashraf U, Zhu P, Yasin Q, Anees A, Imraz M, Mangi HN, Shakeel S (2019) Classification of reservoir facies using well log and 3D seismic attributes for prospect evaluation and field development: a case study of Sawan gas field, Pakistan. J Petrol Sci Eng $175: 338-351$

Ashraf U, Zhang H, Anees A, Ali M, Zhang X, Shakeel Abbasi S, Nasir Mangi H (2020) Controls on reservoir heterogeneity of a shallowmarine reservoir in Sawan gas field, SE Pakistan: implications for reservoir quality prediction using acoustic impedance inversion. Water 12(11):2972

Ashraf U, Zhang H, Anees A, Mangi HN, Ali M, Zhang X, Tan S (2021) A core logging, machine learning and geostatistical modeling interactive approach for subsurface imaging of lenticular geobodies in a clastic depositional system SE Pakistan. Nat Resour Res 30(3):2807-2830

Attia MM, Abudeif AM, Radwan AE (2015) Petrophysical analysis and hydrocarbon potentialities of the untested Middle Miocene Sidri and Baba sandstone of Belayim Formation, Badri field, Gulf of Suez. Egypt J African Earth Sci 109:120-130

Balan E, Saitta AM Mauri F, Calas G (2001) First-principles modeling of the infrared spectrum of kaolinite. In: American mineralogist. pp 1321-1330

Blanc P, Gherardi F, Vieillard P, Marty NCM, Gailhanou H, Gaboreau $S$ et al (2021) Thermodynamics for clay minerals: Calculation tools and application to the case of illite/smectite interstratified minerals. Appl Geochem 130:104986

Bodine MW, Fernalld TH (1973) EDTA dissolution of gypsum, anhydrite, and Ca-Mg carbonates. J Sediment Res 43:4 (1152.1156)
Causey GL (1991) Computer determination and comparison of volume of clay derived from petrophysical and laboratory analysis (Doctoral dissertation, Texas Tech University)

Changwen D, Linker R, Shaviv A (2007) Characterization of soils using photoacoustic mid-infrared spectroscopy. In: applied spectroscopy. pp 1063-1067

Chen H, Li Q, Wang M, Ji D, Tan W (2020) XPS and two-dimensional FTIR correlation analysis on the binding characteristics of humic acid onto kaolinite surface. Sci Total Environ 724:138154

Djomgoue P, Njopwouo D (2013) FT-IR spectroscopy applied for surface clays characterization. J Surface Eng Mater Adv Technol 3(4):275-282

Du C, Zhou G, Deng J, Zhou J (2010). Characterization of soil clay minerals using mid-infrared spectroscopy. In: molecular environmental soil science at the interfaces in the earth's critical zone (pp 265-268). Springer, Berlin, Heidelberg

El-Shater A, Mansour AM, Osman MR, Abd El Ghany AA, Abd ElSamee A (2021) Evolution and significance of clay minerals in the Esna Shale formation at Dababiya area, Luxor Egypt. Egypt J Pet 30(2):9-16

Farmer VC (2000) Transverse and longitudinal crystal modes associated with $\mathrm{OH}$ stretching vibrations in single crystals of kaolinite and dickite. In: spectrochimica acta part A: molecular and biomolecular spectroscopy. pp 927-930

Hasan MN, Yeasmin R, Rahman M, Potter-McIntyre S (2020) Diagenetic clay minerals and their controls on reservoir properties of the Shahbazpur gas field (Bengal Basin, Bangladesh). Geosciences 10(7):250

Hong D, Cao J, Wu T, Dang S, Hu W, Yao S (2020) Authigenic clay minerals and calcite dissolution influence reservoir quality in tight sandstones: insights from the central Junggar Basin. NW China Energy Geosci 1(1-2):8-19

Hucheng D, Meiyan F, Wen Z, Liying Z, Xinhui X, Yilin L et al (2021) The pores evolution of lacustrine shale induced by smectiteto-illite conversion and hydrocarbon generation: upper Triassic Yanchang Formation, Ordos Basin, China. J Petrol Sci Eng 202:108460

Jackson ML, Barak P (2005) Soil chemical analysis: advanced course. UW-Madison Libraries Parallel Press

Ji J, Ge Y, Balsam W, Damuth JE, Chen J (2009) Rapid identification of dolomite using a Fourier transform infrared spectrophotometer (FTIR): a fast method for identifying Heinrich events in IODP Site U1308. Mar Geol 258(1-4):60-68

Jiu B, Huang W, Li Y, He M (2021) Influence of clay minerals and cementation on pore throat of tight sandstone gas reservoir in the eastern Ordos Basin, China. J Nat Gas Sci Eng 87:103762

Jozanikohan G (2017) On the development of a non-linear calibration relationship for the purpose of clay content estimation from the natural gamma ray log. Int J Geo-Eng 8(1):21

Jozanikohan G, Norouzi GH, Sahabi F, Memarian H, Moshiri B (2015) The application of multilayer perceptron neural network in volume of clay estimation: case study of Shurijeh gas reservoir, Northeastern Iran. J Nat Gas Sci Eng 22(1):119-131

Jozanikohan G, Sahabi F, Norouzi GH, Memarian H, Moshiri B (2016) Quantitative analysis of the clay minerals in the Shurijeh reservoir Formation using combined X-ray analytical techniques. Russian Geol Geophys 57(7):1048-1063

Kasprzhitskii A, Lazorenko G, Khater A, Yavna V (2018) Mid-infrared spectroscopic assessment of plasticity characteristics of clay soils. Minerals 8(5): 184

Kuligiewicz A, Derkowski A (2017) Tightly bound water in smectites. W Druku, Am Mineralogist. https://doi.org/10.2138/ am-2017-5918

Kumar A, Lingfa P (2020) Sodium bentonite and kaolin clays: comparative study on their FT-IR, XRF, and XRD. Mater Today Proc 22:737-742 
Li R, Parnell J (2003) In situ microanalysis of petroleum fluid inclusions by Time of Flight-Secondary Ion Mass Spectrometry as an indicator of evolving oil chemistry: a pilot study in the Bohai Basin, China. J Geochem Explor 78:377-384

Li, Y. (2009) Analysis of Acidity in Oil-Based Matrices by Infrared Spectroscopy. Master thesis, department of Food Science \& Agricultural Chemistry, Macdonald Campus, McGill University Montreal, Quebec, Canada

Lin R, Ritz GP (1993) Studying individual macerals using ir microspectrometry, and implications on oil versus gas/condensate proneness and "low-rank" generation. Org Geochem 20(6):695-706

Liu Y, Wang A, Freemen JJ (2009) Raman, MIR, and NIR spectroscopic study of calcium sulfates: gypsum, bassanite, and anhydrite. In: lunar and planetary science conference. pp 2128-2129

Ma F, Du C, Zhang Y, Xu X, Zhou J (2021) LIBS and FTIR-ATR spectroscopy studies of mineral-organic associations in saline soil. Land Degrad Dev 32(4):1786-1795

Madejová J, Komadel P (2001) Baseline studies of the clay minerals society source clays: infrared methods. In: clays and clay minerals. pp 410-432

Madejová J, Bujdak J, Janek M, Komadel P (1998) Comparative FT-IR study of structural modifications during acid treatment of dioctahedral smectites and hectorite. In: spectrochimica acta part a: molecular and biomolecular spectroscopy. pp 1397

Madejová J (2003) FTIR techniques in clay mineral studies.In: Vibrational spectroscopy. pp 1-10

Matteson A, Herron MM (1993) Quantitative mineral analysis by Fourier transform infrared spectroscopy. In: SCA conference (No. 9308)

Meunier A (2005) Clays. Springer Science \& Business Media, Berlin

Moore DM, Reynolds RC (1989) X-ray Diffraction and the Identification and Analysis of Clay Minerals. Oxford University Press, Oxford

Nayak PS, Singh BK (2007) Instrumental characterization of clay by XRF, XRD and FTIR. Bull Mater Sci 30:235-238

Paktunc AD (2001) MODAN-a computer program for estimating mineral quantities based on bulk composition: windows version. Comput Geosci-UK 27(7):883-886

Pálková H, Kureková V, Madejová J, Netriová Z, Uhlík P, Varga P et al (2020) Determination of water content in raw perlites: Combination of NIR spectroscopy and thermoanalytical methods. Spectrochimica Acta Part a: Mol Biomol Spectroscopy 240:118517

Papakosta V, Lopez-Costas O, Isaksson S (2020) Multi-method (FTIR, XRD, PXRF) analysis of Ertebølle pottery ceramics from Scania, southern Sweden. Archaeometry 62(4):677-693

Pineau M, Baron F, Mathian M, Le Deit L, Rondeau B, Allard T, et al (2020). Estimating kaolinite crystallinity using near-infrared spectroscopy. In: 51st Lunar and planetary science conference

Prandel LV, Saab SC, Brinatti AM, Giarola NFB, Leite WC, Cassaro FAM (2014) Mineralogical analysis of clays in hardsetting soil horizons, by X-ray fluorescence and X-ray diffraction using Rietveld method. Radiat Phys Chem 95:65-68

Primpke S, Fischer M, Lorenz C, Gerdts G, Scholz-Böttcher BM (2020) Comparison of pyrolysis gas chromatography/mass spectrometry and hyperspectral FTIR imaging spectroscopy for the analysis of microplastics. Anal Bioanal Chem 412(30):8283-8298

Radwan AE (2021a) Modeling the depositional environment of the sandstone reservoir in the Middle Miocene Sidri Member, Badri Field, Gulf of Suez Basin, Egypt: integration of gamma-ray log patterns and petrographic characteristics of lithology. Nat Resour Res 30(1):431-449

Radwan AE (2021b) Integrated reservoir, geology, and production data for reservoir damage analysis: a case study of the Miocene sandstone reservoir, Gulf of Suez Egypt. Interpretation 9(4):SH27-SH37
Radwan AE, Abudeif AM, Attia MM, Mahmoud MA (2019) Development of formation damage diagnosis workflow, application on Hammam Faraun reservoir: a case study, Gulf of Suez Egypt. J African Earth Sci 153:42-53

Radwan AE, Abudeif AM, Attia MM (2020) Investigative petrophysical fingerprint technique using conventional and synthetic logs in siliciclastic reservoirs: a case study, Gulf of Suez basin Egypt. J African Earth Sci 167:103868

Radwan AE, Nabawy BS, Kassem AA, Hussein WS (2021b) Implementation of rock typing on waterflooding process during secondary recovery in oil reservoirs: a case study, El Morgan Oil Field, Gulf of Suez. Egypt Nat Resour Res 30(2):1667-1696

Radwan AE, Rohais S, Chiarella D (2021a). Combined stratigraphicstructural play characterization in hydrocarbon exploration: a case study of Middle Miocene sandstones, Gulf of Suez basin, Egypt. J Asian Earth Sci, 104686

Radwan AE, Wood DA, Abudeif AM, Attia MM, Mahmoud M, Kassem AA, Kania M (2021c). Reservoir formation damage; reasons and mitigation: a case study of the Cambrian-Ordovician Nubian 'C'Sandstone Gas and Oil Reservoir from the Gulf of Suez Rift Basin. Arabian J Sci Eng, 1-18

Radwan AE (2020). Effect of clay minerals in oil and gas formation damage problems and production decline: a case study, Gulf of Suez, Egypt. AAPG/datapages

Repacholi MH (1994) Clay mineralogy: spectroscopic and chemical determinative methods. Springer Science \& Business Media, Berlin

Scholze B, Meier D (2001) Characterization of the water-insoluble fraction from pyrolysis oil (pyrolytic lignin). Part I. PY-GC/MS, FTIR, and functional groups. J Analytic Appl Pyroly 60(1):41-54

Shen DK, Gu S, Bridgwater AV (2010) Study on the pyrolytic behaviour of xylan-based hemicellulose using TG-FTIR and Py-GCFTIR. J Anal Appl Pyrol 87(2):199-206

Stanienda K (2016) Mineral phases in carbonate rocks of the Górażdże beds from the area of Opole Silesia. Gospodarka Surowcami Mineralnymi 32(3):67-92

Tyagi B, Chudasama CD, Jasra RV (2006) Determination of structural modification in acid activated montmorillonite clay by FT-IR spectroscopy. Spectrochimica Acta Part a: Mol Biomol Spectroscopy. 46(2):273-278

Uusitalo S, Soudunsaari T, Sumen J, Haavisto O, Kaartinen J, Huuskonen J et al (2020) Online analysis of minerals from sulfide ore using near-infrared Raman spectroscopy. J Raman Spectrosc 51(6):978-988

Vaculíková L, Plevová E (2005) Identification of clay minerals and micas in sedimentary rocks. Acta Geodynamica Et Geomaterialia 2(2):67-175

Wang R, Shi W, Xie X, Zhang W, Qin S, Liu K et al (2020) Clay mineral content, type, and their effects on pore throat structure and reservoir properties: Insight from the Permian tight sandstones in the Hangjinqi area, north Ordos Basin China. Marine Petroleum Geol 115:104281

Worasith N, Goodman BA, Neampan J, Jeyachoke N, Thiravetyan $P$ (2011) Characterization of modified kaolin from the Ranong deposit Thailand by XRD, XRF, SEM FTIR and EPR Techniques. Clay Miner 46(4):539-559

Wright MC, Court RW, Kafantaris FCA, Spathopoulos F, Sephton MA (2015) A new rapid method for shale oil and shale gas assessment. Fuel 153:231-239

Yan B, Liu S, Chastain ML, Yang S, Chen J (2021) A new FTIR method for estimating the firing temperature of ceramic bronzecasting moulds from early China. Sci Rep 11(1):1-10

Yousefi B, Castanedo CI, Maldague XP, Beaudoin G (2020) Assessing the reliability of an automated system for mineral identification using LWIR hyperspectral infrared imagery. Minerals Eng 155:106409

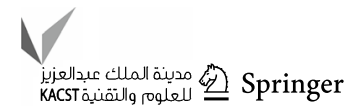


Zhang X, Zhang H, Chang F, Ashraf U, Peng W, Wu H, Duan L (2020) Application of corrected methods for high-resolution XRF core scanning elements in lake sediments. Appl Sci 10(22):8012

Zhang X, Zhang H, Chang F, Ashraf U, Wu H, Peng W, Duan L (2021) Sedimentary grain-size record of Holocene runoff fluctuations in the Lake Lugu watershed. SE Tibetan Plateau Holocene 31(3):346-355
Publisher's Note Springer Nature remains neutral with regard to jurisdictional claims in published maps and institutional affiliations. 